\section{anthropology} \& materialism

\section{Anthropology \& Materialism}

A Journal of Social Research

1 | 2013

Across the Fields

\title{
In the Magnetic Fields of Materialism and Anthropology
}

Dans les champs magnétiques du matérialisme et de l'anthropologie

En los campos magnéticos del materialismo y de la antropología

\section{Marc Berdet}

Translator. Kristina Lebedeva

\section{(2) OpenEdition}

\section{Journals}

Electronic version

URL: http://journals.openedition.org/am/431

DOI: $10.4000 / a m .431$

ISSN: $2364-0480$

Publisher:

CETCOPRA, CRASSH - Center for Research in the Arts Social Sciences and Humanities, Fakultät

Gestaltung - Universität der Künste Berlin

\section{Electronic reference}

Marc Berdet, «In the Magnetic Fields of Materialism and Anthropology », Anthropology \& Materialism

[Online], 1 | 2013, Online since 15 October 2013, connection on 10 December 2020. URL : http:// journals.openedition.org/am/431 ; DOI : https://doi.org/10.4000/am.431

This text was automatically generated on 10 December 2020.

Tous droits réservés 


\title{
In the Magnetic Fields of Materialism and Anthropology
}

\author{
Dans les champs magnétiques du matérialisme et de l'anthropologie \\ En los campos magnéticos del materialismo y de la antropología
}

\section{Marc Berdet}

Translation : Kristina Lebedeva

For all those points in which, despite our most fundamental and concrete agreement in other matters, I differ from you could be summed up and characterized as an anthropological materialism that I cannot accept. It is as if for you the human body represents the measure of all concreteness.

The direct inference from the duty on wine to L'âme du vin imputes to phenomena precisely the kind of spontaneity, tangibility and density which

they have lost under capitalism. This sort of immediate-I would almost say again

'anthropological'-materialism harbours a profoundly romantic element [...] If one wanted

to put it rather drastically, one could say that your study is located at the crossroads of magic and positivism.

Theodor Adorno to Walter Benjamin, September 6, 1936 and November 10, 1938

Here we see the interaction of anthropology and materialism. The reader will immediately wonder: what happens when anthropology turns into materialism? And when materialism becomes anthropology? Does the expression add one more oxymoron to the market of equivocal slogans? No. It generates a precise polarisation that creates a magnetic field within the discomfort which we hope to inhabit. It leads, in 
one direction, to a materialist anthropology and, in the other, to an anthropological materialism as it was outlined by Walter Benjamin ${ }^{1}$.

2 This issue is divided into four sections. The first section includes theoretical articles that address the materialism of different representatives of critical theory (1. Social theory). The second section gathers together Walter Benjamin's radio play, an interpretation of his relations to the new media and the child's play, as well as analyses of a Berlin monument and modern phantasmagorias (2. Materialist experimentations). The third section contains a discussion of traditionally critical conceptions of the State (3. Polemics), and the fourth has a review of a collective work on Charles Fourier and Walter Benjamin (4. Reviews).

\section{Seven preliminary remarks}

3 In the present issue, we will focus primarily on anthropological materialism. It would be inappropriate to attempt here a positive and determinate definition of this term. However, it seems useful, by way of experimentation, to attempt a brief formalisation. These seven remarks thus aim to define anthropological materialism as the active principle of Walter Benjamin's thought, as we understand it today ${ }^{2}$.

4 A SINGULAR TRADITION. With Walter Benjamin, anthropological materialism retrospectively designates a group of very different authors, of French or German tongue, from the $19^{\text {th }}$ century and the 1930s. These authors do not form a selfproclaimed group, do not explicitly relate to each other, and never lay claim to a type of particular materialism.

5 A POLEMICAL TERM. Anthropological materialism is never conflated, stricto sensu, with scientific socialism nor with a common romantic Marxism, nor with any kind of humanism (even though it contains scientific, romantic or humanist elements) ${ }^{3}$.

6 A SENSIBILITY. Anthropological materialism is a method or, more precisely, a sensibility. The latter turns out to be able to capture a moment of play at the heart of action and a poetic intensity within history that the nets of traditional materialism fail to capture. This poetic materialism functions like a metonymy that would indicate a historical kernel that is impossible to symbolise without immediately dissolving its specificity.

7 A TEMPORALITY. Anthropological materialism embodies a vertical temporality that interrupts both the horizontal temporality of the victorious march of conquering "heroes" and the cyclical temporality of the industry that produces commodities.

8 A CONCEPT. Anthropological materialism is a concept that allows one to "correct" dialectical materialism. It certainly allows us to understand Walter Benjamin in a new light. Above all, it indicates a work in progress in Benjamin himself, which demands of us that we refresh its method.

9 AN INTERNAL CONCEPT. Historical materialism includes anthropological materialism, even though historical materialism was not fully aware of it. Anthropological materialism has to be deliberately "integrated" (and not disintegrated) into historical materialism. In other words, it has to be maintained at the heart of historical materialism as an element that remains foreign to it.

10 AN ACTUALITY. Tied to the dialectical analysis of capital, anthropological materialism helps us understand our present. It allows us to locate the forces of intoxication 
enclosed within a collective imaginary subject to the fetishism of market value, which we will call phantasmagoria ${ }^{4}$.

\section{Anthropological materialism}

11 Three contributions extend these remarks. The opening article by Marc Berdet offers a first positive definition of anthropological materialism: it has nothing, or very little, to do with the materialism of Feuerbach 5 . It has to do with a strange "tradition" evoked by Walter Benjamin by way of a rhapsodical enumeration of heterogeneous writers. Indeed, Berdet brings out five great "families" and, by pulling on one thread from the philosopher's work, reveals what might form a common principle within them: expressing forces of attraction and repulsion of the natural world in the human. Displacing the conceptual framework of dialectical materialism, anthropological materialism would amount to the bizarre and poetic translation of Newton into Jean Paul, Büchner, Fourier, Balzac and Rimbaud (“A 'stupefying' materialism. Between anthropological and dialectical materialism").

"Rimbaud with Marx": Michael Löwy takes up André Breton's watchword to interpret the anthropological materialism of the Surrealists. Anthropological materialism participates in an anti-capitalist romanticism that Marxism has to integrate if it wants to be really critical, and not abandon utopia ${ }^{6}$. In this sense, the Surrealist movement embodies a rebellion against the disenchantment and instrumental rationality proper to the capitalist civilisation. Anthropological and dialectical materialism thus create an alloy in the alchemical sense of the term. The no-less alchemical "profane illuminations", integrated into the revolutionary project, are its paradigmatic example ("Walter Benjamin and Surrealism: the Chemical Nuptials of two Materialisms").

"Fourier with Marx": anthropological materialism is also the way in which Walter Benjamin brings together the harmony of human passions and the revolutionary movement, the phalanstery and The Manifesto. Carlos Perez's review of a Cahier Fourier, which is especially dedicated to the relations between Fourier and Benjamin, suggests numerous leads allowing one to critically articulate this poetic materialism with the Marxist tradition.

14 Each of these texts, in a very different way, offers an idea of what anthropological materialism could be. But the interaction between materialism and anthropology is not limited to this. It also creates, under the sign of a broader critical theory, a new type of anthropology, which one could call "materialist anthropology".

\section{Materialist anthropology}

15 Dennis Johanssen's article examines this encounter from the perspective of four authors belonging to this critical theory. The materialist necessity of historicising all human action leads Max Horkheimer to condemn the German anthropology of his time, which today is again at the forefront. A positive anthropology seems to him impossible and even condemnable. For Theodor Adorno, the simple use of the word "human" is demagogical. Any ethnology or cultural anthropology that lays claim to a "positive" definition of human being often lapse into positivism pure and simple. Ulrich Sonnenmann, the little-known author of Negative Anthropology, tried to realise the 
program of a dialectical and materialist anthropology that Adorno wished for. Abandoning a positive (as well as the Marxist) conception of the human being is the only way to open up from it all possibilities of history-on the path of utopia. From this perspective, Walter Benjamin's critical-utopian anthropology supplies us with tools for understanding our present. Competing with today's philosophical anthropology, its theology is essentially nothing but a materialist strategy for diagnosing our time ("The Constellation of Negative Anthropology: Between Critical Theory and Philosophical Anthropology").

16 A materialist theology: this is not the least of the paradoxes that Sami Khatib points out in his text. Indeed, at the heart of human relations there is a "weak Messianic power" which allows for the interruption of the cycle of oppression. Benjamin's Messianism turns out to be less a theological notion than a conceptual operation that allows one to locate, in the profane world, a power likely to cause a stop in the catastrophic unfolding of history. To transform a small deviation into a big one at the heart of social capitalist relations: such is the intention that orients the German philosopher's materialism ("The Messianic Without Messianism: Walter Benjamin's Materialist Theology").

17 Thus, to explode the homogenous and empty temporality of the victors' history. Certainly, but "you can't explode a social relation!" This paradox is the anarchist point of departure of Christos Lynteris' polemic. The latter is mounted against the State not as a "cold monster", external to the individual, but as a social relation that this very individual renews at every moment. Inspired by Gustav Landauer on the explicit terrain of a materialist, if not libertarian anthropology, this polemic seems to politically translate Walter Benjamin's materialist theology ("The State as a Social Relation").

\section{The arch of materialist experimentations}

18 Anthropological materialism and materialist anthropology form an arch of tension in which we perform six "materialist experimentations", six attempts at making theory go beyond itself so as to communicate it to the world and for the world to leave its mark on it.

These six Marxist experiments are organised according to three moments: "Materialist experimentation \# 1: Walter Benjamin and the radio"; "Materialist experimentation \# 2: The phantasmagorias then and now"; "Materialist experimentation \# 3: Walter Benjamin in Berlin today". These three parts constitute different instances of exploring the terrain discovered at the crossroads of anthropological materialism and materialist anthropology.

20 A materialist pedagogue par excellence, Walter Benjamin himself sought to broadcast some experiments in his radio essays, to the children. His play "Radau um Kasperl", which we are republishing here, attests to this simultaneously playful and instructive endeavor. For not only did Walter Benjamin write this play, but he also interpreted it on air, playing with his tone and expressive articulation so as to put himself in the shoes of the little unruly Kasperl ("Radau um Kasperl").

21 We owe this discovery to Philippe Baudouin. In his text, he describes how, over the course of his research, he found a voice that he thought was Walter Benjamin's and 
how Stéphane Hessel (the last living man on this earth who knew the philosopher) confirmed it. A radio artist himself, Baudouin retraced the path of this radioman that was Walter Benjamin: the philosophical path of a thinker who took technology seriously and explored its possibilities; the anthropological path of a materialist who took childhood seriously and explored its potentialities ("'Give to Listener what they Want and Even a little Bit more': A Philosopher on Air").

Stefano Marchesoni in some way takes Walter Benjamin's gesture examined by Baudouin further. "Aufklärung für Kinder" was the title of the philosopher's collection of radio stories. "Walter Benjamin for Children" could have been the title of the talk that Marchesoni addressed to children from ages 9 up to 11. We are reproducing it here. Its actual title is "What Can a Child Do? Walter Benjamin's Toy Story". As a little materialist experiment seeking to explain Walter Benjamin through the universe of play, Marchesoni's talk reaches into children's common imagination so that they follow in the footsteps of little Kasperl. A child discovers what he can really do through a mimetic play with the forces of this world ("Was kann ein Kind? Walter Benjamins Toy Story").

Stefano Marchesoni and Meike Schmidt-Gleim enlighten the adults about this. Their text relates the mimetic power to a creative potentiality, which, like the "weak Messianic force", can break the cycle of exploitation and repression. The child puts himself in the doctor's shoes, but also in those of the train: in every children's play there is thus a moment of imitating the world that is, properly speaking, the poetic moment of human creativity ("Bemerkungen über Mimetismus und Kindheit").

However, poetic intensity has to be reestablished within human creation from the perspective of the oppressed, combatant class that retains within it the memory of past generations. This is the claim one of the eight theses Marc Berdet presents on phantasmagoria, the bourgeois imaginary that is materialised in the architectural and city environment to imprison potentially subversive Fourierist passions within it. Today, this text intends to engage with the analysis of the Parisian arcades started by Walter Benjamin almost a hundred years ago ("Eight Theses on Phantasmagoria").

In an experimental dialogue, Christos Lynteris responds to these eight theses in ten short comments that mobilise contemporary anthropology and psychoanalysis. The obsessive, mythic repetition of phantasmagoria thus reveals the close link between this passional creativity and the inertia of the death drive ("Ten Comments on 'Eight Theses"').

Integrated into historical materialism, on the contrary, anthropological materialism reintroduces this poetic vertigo into the activity of the researcher. Joanna Kusiak's "materialist experimentation" traces Benjamin's activity. It has to do with capturing heterogeneous materials that revolve around the same phenomenon to crystallise in them: a) historical unfolding, b) political polarisation, and c) poetic intensity. Here empirical phenomenon is the massive monumental statue of Ernst Thälmann, north of Berlin in the district of Prenzlauer Berg. This socialist monument that the city could not demolish for lack of money remains at a distance from the tourist circuitry: neither onlookers of planetary tourism nor the "alternatives" venture to go there. The politics of the "poor but sexy" capital is struggling to integrate it into its enterprise of seduction. Like a black hole, this monument seems to attract the practices that the city would like to expunge, notably, after recent history, the cleansing rituals of those nostalgic for Communism and the vandalism of neo-Nazis. On the basis of this example, 
Kusiak confronts Walter Benjamin's materialism alongside a particularly pertinent questioning: where to stop oneself in the collection of materials? When to capture the poetic intensity that surges up in them? How to polarise its moments to make a "dialectical image" from them ("Striking Dialectical Sparks from the Stones of Our Cities: Learning from Ernst-Thälmann-Monument in Berlin with Benjamin's Materialist Methodology")?

\section{The key to the fields}

Nevertheless, anthropological materialism and materialist anthropology do not stop there. What are the modern myths that surround us today? We will discuss this question in the next issue ${ }^{7}$. The following issues will have to do with technology, utopia and ideology, hoping that the field opened up by the journal generates new hypotheses about each of these subjects.

The journal inaugurates a fruitful interaction of materialism and anthropology that can follow methodological paths opened up by still different authors, which we inherit. We are thinking specifically of Michel Foucault's works, of this real anthropology constructed on the basis of relations of forces between human beings. The notion of biopolitics, for instance, allows one to analyse the way in which power captures biological forces ${ }^{8}$. The "materialism of the encounter" or the "aleatory" materialism of the later Louis Althusser has the sense of a poetic materialism as we understand it here, especially since it allows us to analyse the strategy of the bourgeoisie as the "magical and spectacular reign of entertainment". Political anthropologies, like those of Pierre Clastres', who critiqued Marxist economism, or like that of Michael Taussig ${ }^{10}$, who took up some of Benjamin's theses, could also be part of a materialist anthropology. In fact, historical materialism was too often limited to the single economic contradiction. Its confrontation with anthropology opens it up to the wealth of human contradictions both at the individual level of social physiognomies and the collective level of spatial organisation, not to mention architecture, new technologies, or childhood games.

In short, the encounter of materialism and anthropology could, beyond disciplinary confines, play the role of a developer, in the photographic sense of the word, of new researches. Combined with a critical analysis of domination, they would keep an attentive eye on rebellious, possibly liberating magnetisms. Let us then hope that this interaction makes sparks fly and that it helps open up the horizon of the possible that is somewhat obstructed by our age.

\section{BIBLIOGRAPHY}

Abensour, M. 2000. L'Utopie de Thomas More à Walter Benjamin. Paris: Sens et Tonka.

Adorno, T. W. 2000. The Complete Correspondence: 1928 - 1940. Cambridge: Polity Press.

Althusser, L. 1994. Sur la philosophie. Paris: Gallimard. 
Benjamin, W. 1978. "Surrealism: The Last Snapshot of the European Intelligentsia”. New Left Review I/108, March-April.

Benjamin, W. 1999. The Arcades Project. Cambridge, Mass.: Belknap Press.

Clastres, P. 2010. Archéologie de la violence. Paris: Aube.

Clastres, P. 1974. La société contre l'Etat. Paris: Minuit.

Foucault, M. 2001. Dits et écrits 2. Paris: Gallimard.

Foucault, M. 2008. The Birth of Biopolitics: Lectures at the College de France, 1978-1979. Basingstoke: Palgrave Macmillan.

Marx, K. 1970. The German Ideology. New York: International Publishers.

Taussig, M. 1993. Mimesis and Alterity: A Particular History of the Senses. London: Routledge.

Taussig, M. 2009. What Color is the Sacred? Chicago: University of Chicago Press.

Websites:

http://anthropologicalmaterialism.hypotheses.org/

http://biopolitica.cl/ingles/pags/portada.html

\section{NOTES}

1. Especially in his 1929 essay on surrealism (Benjamin 1978) and his great unfinished work, The Arcades Project (Benjamin 1999). However, one also finds it elsewhere. See the work undertaken on www.anthropologicalmaterialism.hypotheses.org

2. I published the first draft of these seven remarks on the aforementioned internet site. I thank Sami Khatib and Jan Sieber for their comments on the subject, as well as Carlos Perez and Sébastien Broca for their suggestions for the introduction in its entirety.

3. The expression "anthropological materialism" is also used by Adorno during a polemical exchange with Walter Benjamin. See the citations used as an epigraph, corresponding Adorno's letters from September 6, 1936, and November 10, 1938 (Adorno $2000: 146,283$ ).

4. On this subject, see "Eight Theses on Phantasmagoria" below.

5. Feuerbach replaced words with things: he wrested the phenomena from the realm of Hegelian ideas to put them into the natural world. This still a-historical materialism was "historicised" and then "dialectised" by Marx and Engels, opening a royal but problematic road to scientific socialism, sociology, anthropology, social history and philosophy. See Marx's classic critique of Feuerbach (1970).

6. Especially according to the perspectives opened up by Miguel Abensour in L'Utopie de Thomas More à Walter Benjamin (2000).

7. A call for papers is already available online here: http:// anthropologicalmaterialism.hypotheses.org/1018

8. See, for example, Michel Foucault, Dits et écrits 2, (2001) and The Birth of Biopolitics: Lectures at the College de France, 1978-1979 (2008). An international, Santiago-based network has developed around this problematic, which can be seen on http://biopolitica.cl/ingles/pags/portada.html

9. Althusser $1994: 25$.

10. Indeed, Pierre Clastres has demonstrated the way in which what gets organized materially at the heart of a group is the impossibility of the emergence of a hierarchical power or head of state. See his classic text La société contre l'Etat (1974) but also Archéologie de la violence (2010). 
Michael Taussig is inspired by Benjamin in Mimesis and Alterity. A Particular History of the Senses (1993) or, more recently, What Color is the Sacred? (2009).

\section{AUTHORS}

\section{MARC BERDET}

Doctor of Sociology, Paris Sorbonne University, Marie Curie Fellow (EU) at the Faculty of Philosophy, University of Potsdam 